\title{
Violence against women as an obstacle to women's productivity in Nigeria: A challenge to recreate contemporary Nigerian society
}

\section{Christian Chima Chukwu* and Ignatius Sunday Ume}

Novena University. Department of Sociology. Ogume. Delta State. Nigeria. *Email: chukwuchidr@gmail.com.

\begin{abstract}
Women's lives and their bodies have been the unacknowledged casualties of men for too long. As a result of violence perpetrated against them, their productivity in workplaces have decreased over time. Understanding that productivity improvement is a key objective for industries, the thrust of the study is, therefore, to evaluate, from a sociological perspective, the consequences of violence on women's productivity in contemporary Nigerian society. A sample 595 respondents was selected through the multistage sampling techniques amongst working class women. The questionnaire was subjected to face and content validation by experts from gender and women studies. Chi-square was adopted to test the hypotheses at 0.05 levels of significance. Findings reveal that violence against women disrupts women's lives, destroys their health, undermines their confidence, and takes away their psychological sense of esteem, as well as undermines their full participation in social life. Secondly, the study show that women make several medical visits every year to treat injuries resulting from assaults by spouse thereby limiting the number of hours spent in the office. Essentially, violence against women lessens the woman's inability to work and promote productivity. Based on this, the study concludes that since women represent an important population group in Nigeria, there is an urgent need to address marital violence against them, particularly those in the formal sector of the economy because they make meaningful contributions to the overall labour force and general societal well-being of all and sundry. In view of this, the study recommends, amongst others, that government through state and non-state actions should ensure the strict enforcement of laws that protect women's rights, as well as deter their partners from subjecting them to violence. In addition, educational and religious institutions should re-orientate men to be more accommodating in their relationship with their women partners on the ills associated with marital violence particularly wife abuse, with a view to getting them unlearn such violent behaviours. Finally, there is a need for advocacy and concerted action that will involve the educational, health, civil and religious sectors of the society to evolve sustainable structures that will empower women and
\end{abstract}

Received

February 19, 2020

Accepted

April 27, 2020

Release

Apr. 30, 2020

Open access

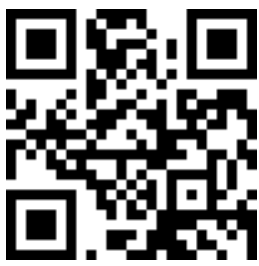

ORCID

D 0000-0002-4290-234X

Christian Chima

Chukwu

D) 0000-0001-8044-3351 Ignatius Sunday Ume

ISSN 2359-1412/BJBS-2020-0010/2020/7/15/8/79

Braz. J. Biol. Sci.

http://revista.rebibio.net 
provide support to enable victims to react appropriately to violence.

Keywords: Marital violence; Labour productivity; Nongovernmental organizations; Counselling.

\section{Introduction}

One of the most enveloping infringements of human rights in all developing societies, particularly Nigeria is the violence perpetrated by a cherished spouse against the other who was once found irresistible. Nowadays, the wave of brutality against women sexual, psychological, and socio-economic has become extensive across the Nigerian society than ever before, not necessarily because the evils inherent in the act are not despicable but because Nigeria is a patriarchal society where women are located in the other room. Of recent, violence has absconded from the home as if it were human and migrated into workplaces lowering productivity as never before. Without mincing words, violence against women is a major threat to economic productivity which is measured as a ratio of outputs to inputs. As a fundamental concept, labour productivity is the result of workers' ability to increase yield in the absence of hostile environment. Since there is no exceptional method for determining productivity in organizations in order to ascertain the level of performance, improving performance and increasing productivity requires violence free environment.

The frequency of the cruelty against women has not only become alarming, but a cornerstone for concern in the society because most victims suffer in vain. Put differently, violence, especially against women and girls, is not new, historically it has taken many farms, but in the context of globalization, it has acquired shocking new dimensions. Women are most often killed, seriously injured or permanently disabled. Horrifyingly as it is, it is even estimated that two out of every three women in Nigeria experience physical, sexual and psychological violence from a close partner in the family (Vanguard, 2013). This statistics, though a bit old, is frighteningly higher today than ever before. However, the figures, while not too current as earlier observed, countered previous statistical finding of the gender in Nigeria Report (2012) which contended that one out of every five Nigerian women and girls aged 15-24 years, had been a victim of one form of violence or the other. What is more, cases of seriously injured or permanently disabled women resulting from wife battering as well as sexual aggression such as incest and rape can only be imagined than stated. By implication, it is evident that personal safety is no longer guaranteed in a close partner relationship.

According to varied and sometimes conflicting sources, millions of women worldwide are violently abused, enslaved, and harassed. Violence against women has significant ramifications for international human rights, international criminal law, and the global economy. A significant number of academics and commentators highlight spousal violence as a global problem, affecting all women, rich and poor, black and white, and not only in developed countries, but also in the developing countries. It affects every class of women, rich and poor, educated and uneducated, able and disabled. According to Ilika (2005), women, in many cases, experienced verbal, physical and psychological violence exhibited in scolding and abuses, beating, forced and non-consensual sex. Furthermore, she is beaten mercilessly with her face bruised and battered. In this pain and discomfort, most women have more than the number of pregnancies they would ordinary desire to have. Without fear of contradiction, a woman suffers emotionally more than any other, and is never allowed to express her feelings. In Nigeria, the cruelty the woman experiences parallels the nightmare of many women in all other patriarchal societies. 
Apparently, making women speechless and powerless in matters that affect them is one of the features of the patriarchal inclination that is stomach-turning. Buttressing this assertion further, Eze-Anaba (2007) observes that most forms of violence directed specifically against women in Nigeria seem to be met with silence not only by the state but also by much of the human rights community for the simple reason that these organizations are male dominated.

By this tacit acquiescence, the subordinate condition of women is daily being oiled and enforced by the hidden viciousness of men unceasingly. In effect, the dominated power structure that upholds and entrenches male authority is sustained by cultural institutions, particularly religion which, humiliates and consigns women not only to the other room but to obscurity. Culturally, man is invested with the sole right to decide the fate of a woman. This lone right to subject women, especially wives to various degrees of discriminatory and dehumanizing practices, including rape, is not disheartening, but depressing because men are hardly ever accused of any act of sexual violence (Chukwu and Okey, 2015). Without mincing words, Nigerian society is more or less chauvinistic, and as a result, women are sexual objects of men, and are also what men make them. While agreeing to this view, Charles (2010) contends that women are the targets of sexual violence because men feel a sense of sexual entitlement to them and are therefore socialized to see them as sex objects. As a result, occurrences of brutality against women which range from battery, beatings, torture, acid baths, rape, kidnapping, and even death through honour killing have become worrisome. The implications of this insight are as sickening in the present as they were a century ago.

Underneath the cruelty against women, Uchendu (2007) avers that the biblical story of a woman coming from the rib of a man is evidence that the gender arrangement that places women lower than men is God's decision that requires no debates. This notion held by most male respondents in Uchendu's study (Uchendu, 2007) holds that the male as a category is naturally chosen to lead and control females from creation. In an attempt to consolidate this assertion, various antics are daily being exhibited to control, and where possible, intimidate women despite the changing times. The trend of globalization currently transforming the old order seems to mean nothing. Surprisingly, the brutality against women is hinged on the Biblical gospel of Matthew 11:12 where Jesus is credited with the maxim that "from the days of John the Baptist until now the Kingdom of heaven suffers violence, and the violent take it by force" (Holly Bible, 1982).

While it can be argued that the contentious nature of the quoted verse does not refer to women, it is indeed rather saddening that the Holy Bible and other church documents in other instances support women subjugation and subordination through religious norms and teachings. For example, the Pauline discussions on marriage and the Code of Canon Law (Vatican, 1917) explicitly forbid divorce or exit from marriage. In addition, re-married divorced women are adulteresses who should be denied all forms of Christian church rites and privileges. The Biblical narrative of the creation of a woman as a helper from the rib of a man and Paul's exhortation to wives to be submissive to their husbands summarizes the Christian religious teaching. Wring on this misinterpreted and misrepresented exhortation of Paul in the Bible; it is observed that the inequality between man and woman is even more severe and more strictly observed in Islamic and the heathen religions. Nevertheless, Uchem (2001) has extensively criticized the Christian religious perspective, and also highlighted the implication of such religious perspectives for the reproductive right of women in the Moslem Area of Egypt. In all respects, the woman is powerlessness to voice out her disappointment in a patriarchal society. This notwithstanding, her plight as subjugated and exploited being searching for recognition is further compounded by series of injustices meted to her.

These traumatic events are extraordinary, not because they occur rarely, but rather because the cruelties involved are not one of the adaptable features to life.

Braz. J. Biol. Sci., 2020, Vol. 7, No. 15, p. 79-100. 
Following this, hardly does a day go by without women being categorized, subjugated, oppressed, and even regarded as a piece of furniture. Supporting this line of thought emerges the explanations why men who perpetuate these horrible deeds are wittingly earning the approval of the patriarchal society as real men. Man's supremacy is also predicated in the payment of bride price, a process that conveys and confirms the right of ownership. The process of the payment of bride price where husbands purchase their wives' sexual favours and reproductive capacity, underscores husbands' entitlement to dictate the terms of relationship. Basically, whatever the terms of relationship, the payment of bride price subordinates the woman as something acquired. This is explicitly manifested and glamorized during the marriage ceremony when the young lady kneels in a symbolic gesture of submission while presenting a cup of palm wine to her husband. The women expressed the perception and consciousness of ownership by their husbands repeatedly. The implication is that the abused woman feels obliged to obey, subscribe and succumb to her husband's desires at all times.

The basic fact about bride price aptly summarizes that, women, in all patriarchal Nigerian societies are still being viewed and treated as liabilities rather than as assets. The picture that seems to emerge from the subjugation, oppression and marginalization of women is that of an Ostrich that runs to bury its head in the sand, and convincing itself that no one has seen it, but unknown to it, its entire body is still exposed to all and sundry (Chukwu and Okey, 2015). Chukwu and Okey (2015) asserts that this kind of foolery of being violent towards women for the purposes of maintaining male superiority is simply preposterous because the dangers inherent in the continuous employment of violence against women outweighs the advantage of whatever the perpetrators stand to gain.

From the foregoing discourse, the woman has been displaced, dislodged, disoriented and marginalized. It is, therefore, in alignment with Article 1 of the Universal Declaration of Human Rights that Ikonne (2008) condemns the injustice thus:

\begin{abstract}
A woman is conceived as innately inferior to the man, both physical and mentally. Consequently, far from being encouraged to better herself by acquiring knowledge and engaging in other activities that will challenge her mental capacity and thus enrich it, she is encouraged to spend her days thinking up strategies to attract and hold men.
\end{abstract}

It is ironical that, the woman who was the first to consume the fruit from the tree of knowledge and to whom she gave a piece to the man should nowadays be excluded from the delight of knowledge and treated with disdain. Regrettably, in her offer to exert a pull on and cling to the man, the only occupation she is purportedly fashioned to engage in is not to be her real self, but to feign softness, grace, tenderness and inability to depend on self. These attributes defined by man, are what make a woman.

Aside from being very vulnerable to extreme poverty, hunger and illness, women living in camps for refugees or as internal displaced persons have over time, been subjected to high rates of physical and sexual assault by military personnel. In some ugly scenarios, women and girls are forced to submit to sexual abuse or forfeits food and other basic necessities such as fuel and water. Corroborating, Effah-Chukwuma (2013) avers that violence, and indeed other forms of violence against women, is a power relationship. It is more about men feeling they have power and control over women, and physically and sexually assaulting them into submission. On the other hand, scholars have contended that violence against women, from all intents and purposes, is primarily to checkmate women from their gradual, but steady ascendancy into the positions of economic relevance because of the fear that they might use their new found economic independence to alter the status quo ante at home (i.e. change the power equation at home). 
This study is therefore, articulated with a view to portraying very clearly the extent to which violence against women has become an obstacle to women's productivity in Nigeria with a cause for concern, particularly for the contemporary Nigerian patriarchal society has constituted an impediment to women's efforts to become productive in their different human endeavours. The broad objective of this study is to examine the issue of marital violence and how it affects the labour productivity of women outside the home.

\section{Review of related literature}

\section{Violence against women and International conventions}

Women constitute a recognizable proportion of the entire society, and being violent towards them, especially in their formal places of work would mean depriving society of their usefulness. In addition, it has been realized that given the opportunity, women are capable of positively affecting social life, especially, if the barriers that prevent them from functioning in this direction are removed completely from their way. Above all, the immortal words of Koffi Annan (UN, 2004), erstwhile Secretary General, United Nations, add flesh to same above. He argues that no positive societal change is better than one that involves women as central players. We could deduce from Annan's position that, in any genuine and well meaning human society, by the very fact that it is functional, presupposes the existence of consciously endowed women who could turn things around.

It is a paradox that a love relationship being nurtured by spouses would suddenly turn to a theater of absurdities, leading to several injuries and scattered homes. Writing on the rate of brutality against women by a close partner, Campbell et al. (2004) avers that mortality in children under five years of age has significantly increased. Ordinarily, one would have expected pregnancy to be a protective factor against violence in some societies, but in reality, it is estimated that one in four women across the world is physically or sexually abused during pregnancy, usually by her partner, in some cases leading to serious injury to the fetus, miscarriage, premature labour, and fetal distress, low-birth-weight or death (Campbell et al., 2004).

In a similar vein, Abama and Kwaja (2009) aver that women face some forms of violence during their lifetime, and argue that most governments have considered violence against women (particularly marital violence by a husband or other intimate partner) to be a relatively minor social problem. Despite the growing recognition of violence against women as a public health and human rights concern, and of the obstacle it poses for development, violence against women continues to have grave consequences for women engaged in one form of formal activity or the other.

It is this view that the term 'patriarchy' emerges to describe and analyze the unequal distribution of power between women and men. This power differential, from all intents and purposes, is simply called subordination, oppression, or exploitation. Each of these terms suggests women's relative lack of power and status, but the emphases on each differ slightly.

- Subordination refers to the manner in which patriarchal social structures inevitably produce unequal interpersonal relations between men and women.

- Oppression refers to the manner in which women experience sexism, a process of unfounded social discrimination whereby men claim authority over women.

- Exploitation, a term borrowed from Marxists, refers to the manner in which men appropriate women's skills and industry without rewarding them.

The unequal practices sums up to a systematic form of oppression, and the concept of patriarchy forms a lens through which a system can be viewed. It is this strand of thought that violence has become "pervasive" in Nigeria. About 20 percent of Nigeria 
women experience physical, sexual and psychological violence from spouse or male relative (Vanguard, 2013). The level of violence against women in Nigeria is increasing by the day with two out of every three women in certain communities experiencing violence in the family. It is difficult to determine the extent of violence against women in Nigeria because official statistics on violence in the home are not collected, and as result, incident of spousal violence tends to go unreported. As a result, the problem of spouse violence has become one vexing issue that has in recent times attracted the attention of scholars, particularly those in law, social sciences and medical sciences. This is not only because of the alarming rate at which most Nigerian women are being brutalized on a daily basis for being in close relationships, but also the serious consequences the cruelty holds for victims and the entire society.

Humiliating as it is, patriarchy has propelled discrimination and cruelty against women to attract great concern from international conventions such as that of the UN General Assembly, which passed the Declaration on the Elimination of Violence Against Women (UN, 1993). The body (UN, 1993) offered the first official definition of such violence against women as any act of gender-based violence, which results in or is likely to result in physical, sexual or psychological harm or suffering to women including threats of such acts, coercion or arbitrary deprivation of liberty whether occurring in public or private life. Similarly, the United Nations Convention on the Elimination of All Forms of Discrimination Against Women (UN, 1979), further described discrimination against women as any distinction, exclusion or restriction made on the basis of sex, which has the effect or purpose of impairing or nullifying the recognition, enjoyment or exercise of women, irrespective of their mental status on a basis of quality of men and women, of human rights, and fundamental freedom in political, economic, social, cultural, civil or any other field. In addition, the International Conference on Population and Development (ICPD, 1994) and the Beijing Declaration at the Fourth World Conference on Women in Beijing (1995), re-affirmed these conventions and commitments to eliminate genderbased discrimination and violence. Besides, the African Charter on Human and Peoples Rights (OAU, 1986) specifically (in Article18) urged member-states to ensure elimination of all discriminations against women and also ensure the protection of the rights of women. Although Nigeria is a signatory to most of these treaties, violence against women continues to be pervasive in the country. Rape, battery, and other forms of sexual and domestic violence have become common place that women's lives can hardly be described as outside the range of ordinary experience. It is a paradox that a love relationship nurtured by spouses devotedly could suddenly turn to a theater of absurdities, leading to several injuries and broken homes.

The current rate of spousal violence cannot be established, as there has not been a national survey to that effect (Effah-Chukwuma, 2013). However, following the current trend, one in five Nigerian women is a victim of spousal violence. Elucidating further, Ugube (2004) submits that violence against women is the most degrading, injurious, breach of any man's right both fundamental and human as it involves the use of superior physical strength to cover up for men's inadequacies. Basically, men's insecurity and inferiority complex are the explanations for this unwholesome attitude to intimidate their female counterparts who threaten their ego by trying to be economically independent, Ugube (2004) concludes. Arguing further, Chukwu and Okey (2015) is of the view that men insecurity about the economic independence of women boils down to a question of pride, which stems from the wider cultural and ideological prescription that men feel about their position as the exclusive source of sustenance to the family. This one and only responsibility, they reasoned, is being threatened, and they might be schemed out of the power equation thereby rendering them powerless at home; this ill-wind which will do them no good must be halted hence, the physical violence to cripple women. From this perspective, it is obvious that Nigerians, in spite of the currency against violence against 
women in the international arena are still finding justifications for continued dominance over women for the pleasure of their ego. Corroborating with these assertions, one can assert that close partner violence is a crisis that stems from man's lack of respect and his estimation of women as worthless.

Like any other wicked act, violence against women, especially those involving close partners in Nigeria, has grown in leaps and bounds, winning more victims, who now lament profusely to their continued subjugation and discrimination, and have resigned to fate. Psychologically, violence against women cuts them down to the very core of their being and often times create a sense of worthlessness in them. Most disturbing of all this is the fact that, the Nigerian society is not oblivious of the Beijing Declaration (UN, 1995). The declaration provides an internationally-agreed agenda and strategy for achieving gender equality to compensate for historical and sexual disadvantages of the past, which prevented women and men from operating on a level playing field. Continuing, Ugube (2004) further avers that domestic violence degrades women so much because it is done by their soul mates, the men they have vowed to spend the rest of their lives with. The practice, she says, takes the form of physical beating and injury as well as emotional torture and scorning of the woman's self esteem and self worth. What makes it worse, she concludes, is that women endure such torture in the hope that their mates will change to keep their family together and to avoid societal scrutiny that come from broken marriages.

Thus, it has become needful to mount up strategies that would facilitate the identification of the specific problems confronting women and assist them to overcome such to enable them become active participants in development orientated activities. This study is, therefore, an attempt to highlight marital violence, a cankerworm in the lives of women, particularly those employed in one formal sector or the other. Therefore, the specific focus of this work is on the consequences of marital violence on the labour productivity of employed women.

\section{Broad-spectrum of violence against women}

Violence, according to the Oxford Learner's Dictionary (1995), is that which involves great force or intensity; the use of excessive physical force that ultimately results to injury to that (person or animal) which the great force is being applied upon. Basically, violence is any action, inaction or practice that threatens or works against the emotional, physical, or mental well being of women. The United Nations, under Beijing Declaration and The Platform for Action (UN, 1995), define violence against women as "any act of gender based violence that results or is likely to result in physical, sexual, psychological harm or suffering to women, including threats such as coercion or arbitrary deprivation of liberty, whether occurring in public or private life". Regrettably, many of the victims do not speak out about violations of their rights due to lack of positive response from the society (Haaga et al., 2015). Following this, violence against women is so entrenched in the society that even the victims condone such violations of their rights with some claiming it is a sign of love (Bill, 2003). Furthermore, due to poverty, fear and economic dependence on men, many victims suffer in silence for fear of losing the economic support of the male "perpetrator". Amnesty International (2005) thus observes that where a victim summons the courage to report to law enforcement agents, the issue is trivialized and termed a "private matter".

Fundamentally, violence against women is a gender-based problem, cutting across all societies, and affecting women the world over. The United States Population Reference Bureau (PRB, 2001) reports that it is not limited to poor women or to women in third world countries, but to all women, irrespective of their classes, income groups as well as races. Put differently, it is characteristic of every society and taking different forms as well as occurring in varying dimensions. It is simply an act perpetrated against women because of their identity. 
Basically, marital violence against women takes many forms, from the overt to the subtle (Margolin and Burman, 1993). In its definition of marital violence, WHO (2000) adopted the following definitions of physical and sexual violence to aid in research and programming, concentrating on identifiable acts. Physical violence means a woman has been: slapped, or had something thrown at her; pushed, shoved, or had her hair pulled; hit with a fist or something else that could hurt; choked or burnt; threatened with or had a weapon used against her. Sexual violence means a woman has been: physically forced to have sexual intercourse; had sexual intercourse because she was afraid of what her partner might do; or forced to do something sexual she found degrading or humiliating. Though recognized as a serious and pervasive problem, emotional violence does not yet have a widely accepted definition, but includes, for example, being humiliated or belittled; being scared or intimidated purposefully.

In Nigeria, violence against women occurs mainly in the form of rape, sexual harassment, wife abuse, early and forced marriages female genital mutilation, widowhood practices and male-sex preference (Abayomi and Kolawole, 2013).

Accepting the foregoing, it is obvious that violence against women takes different forms and poses serious hazards to women and also to the society, even though the Nigerian society itself seems to be oblivious of this. It basically threatens the well being and meaningful existence of women as it also deters them from participating effectively in, and contributing meaningfully to social life. In addition, The United Nations Beijing Declaration (UN, 1995) argues that the low socio-economic status of women could be both a cause and a consequence of the violence against them. It further observes that violence instills fear and insecurity into women, restrains their mobility and as well as limits their access to resources and basic activities thereby forcing them into subordinate positions which in the long run, becomes an obstacle to development and the achievement of gender equality.

Still on the dangers of violence against women, Carrillo (1992) says that it maims and debilitates women, as well as serves as a form of control that limits their ability to options in homes, schools, workplaces, etc., and this contradicts the major goal of development for women, which is that of increasing their self-confidence and their ability to participate in all aspects of social life. Carrillo further submits that violence against women disrupts women's lives, gives them no options, undermines their confidence, and takes away whatever is left of their psychological sense of esteem, destroys their health, denies them their fundamental human rights as well as undermines their full participation in social life. Above all, Bart and Moran (1993) are of the position that violence against women are interrelated, coalescing like a girdle to keep women in their place, which is subordination to men. For this study, the term marital violence is interchangeably used with domestic violence because the two terms mean same and one thing, and it is on this note that the review of related literature is focused.

\section{Violence as impediment to women self actualization}

Violence against women occurs in close relationships. Over the years, reports on the problem reveal that women are the main victims of violence in intimate relationships. Comprehensive and systematic studies on the problem have been, and are still being undertaken in different societies by scholars and researchers and the results have always been that women are usually the victims and men the perpetrators. The Baobab Legal Literary Series (2009), a non-governmental organization writes that marital violence is violence within the home and adding that it is carried out mostly by members of the family i.e. the husbands against the wives. Agreeing with this view, Ganny (1996) also observes that one out of every three marriages, experiences physical violence at some point and women are usually the victims. Burns et al. (1997) posit that every day, women are slapped, kicked, beaten, humiliated, threatened, sexually abused and even murdered by 
their partners. Furthermore, the United States Population Reference Bureau in its reports on gender-based violence states, "domestic violence is typically directed at women and girls".

In a related development, the United States National Crime Victimization Survey reports in Brown et al. (1997) that women are about six times more likely than men to experience violence committed by an intimate, adding that in over $90 \%$ of cases of domestic violence between 1987 and 1991, the victims were females. In addition, Brown et al. (1997) reports that one out of every four American women is likely to become a victim of domestic violence, noting that one-third of these violent acts against women are committed by men who claim to love them. They further submit that reports from the American Medical Association show that husbands and boyfriends assault as many as four million women every year. Barnett and Laviolette (1993) argue that as much as $91 \%$ of spousal violence may never come to the attention of the police.

However, in more advanced societies such as the United States, statistical records exist on marital violence. Barnett and Laviolette (1993) observes that by mid 1980s, marital violence had reached such epidemic proportions that the United States Centre for Disease Control began to treat spouse abuse like any other epidemic. For instance, in United States, women, according to these scholars suffer 2,100 injuries annually as a result of marital violence, as compared to 522,000 injuries from car accidents. In conclusion, Barnett and Laviolette (1993) say women make about 1,453,437 medical visits every year to treat injuries resulting from assaults by spouse. Furthermore, the United States Crime Survey Data, according to Roberts (1996), reports the number of visits by women for medical care resulting from domestic violence as follows, 28,700 visits to a hospital emergency room, and 39,000 visits to physicians' offices, 21,000 in patient hospitalization, and 99,800 days of hospitalization.

As stated earlier, there is hardly a properly coordinated statistical data on the issue of marital violence in Nigeria. To this, it is generally agreed that part of the reason is that women seldom report such problems to appropriate authorities for fear of facing further assaults, and secondly, because hardly is anything done about such reports in a patriarchal society like ours. On a general note however, there is no single source of information that can estimate the proportion of the problem of marital violence even as it concerns Western societies (Roberts, 1996). Be that as it may, the few reports and statistics especially from the United States - so far, leaves one in no doubt that in nearly all cases of marital violence, women are the victims.

Accepting the foregoing, Brown et al. (1997) states the following to further buttress the fact that women are the victims of marital violence:

- Women are not battering their husbands in epidemic proportions.

- Women are not regularly beating up their men and leaving them crouched, huddled, sobbing and injured (or worse) on the kitchen floor.

- Men are not fleeing their homes, children in tow.

- Men are not the spouses who live in terror.

The conclusion from Brown et al. (1997) is self explicit: women are obviously the victims of marital violence.

\section{The extent and forms of spousal violence}

Spousal violence is a very common social malady. This is evident in the several reports earlier analyzed. Besides, the United States Population Reference Bureau Reports that marital violence, which classically occurs when a man beats his wife, is the most prevalent form of gender-based violence (Collins et al., 1999). In most cases of marital violence, the situation can at best be described as wife abuse, wife assault or wife battery. 
There is no exception in marital violence as any woman can be a victim of wife abuse, or wife battering. That is, it is not limited to women of a particular social background. In a similar vein, Roberts (1996) writes that although marital violence is experienced by women of all social classes, religions, races and ethnic groups, the problem is however more visible in the lower class or among the lowest income group. This is not to suggest however that, women of the lower class are more vulnerable to abuse by their partners than women of other classes. Thus, Brown et al. (1997) comment that women who are physically and emotionally strong, financially successful, socially accepted and even spiritually ahead of most other women fall into the trap of marital violence just like less healthy women. The United States Population Reference Bureau Report on Gender-Based Violence shows that two to four million women of all races and classes are beaten every year (Collins et al., 1999). Furthermore, the United State Population Reference Bureau reports that marital violence is characteristically directed against women and girls, and it includes battering, burning, emotional blackmail, mockery or ridicule, threats of abandonment, confinement to the home, withholding of money and other family support. For Davis (1994), spousal violence takes the form of physical and sexual violation as well as psychological or mental violence, which consist of repeated verbal abuse, harassment, confinement, deprivation of physical, financial and personal resources, limited contact with family members and friends. According to Brown (1987), physical abuse reports by women ranges from being slapped, punched with a fist, kicked or hurled bodily or being chocked, smothered or bitten. Furthermore, she submits that women also reports cases of marital violence in which they were beaten with an object, threatened or injured with a weapon, scalded with hot liquid, held under water or sexually assaulted.

\section{Spousal violence: An invisible problem}

Spousal violence, wife abuse in particular, constitutes some kind of very common problem, yet it is largely hidden (Dwyer et al., 1996). Okolo (2004) also notes that as common as the problem of wife abuse is, it is largely unknown to the public. In addition, Bradely (1994) also submits that the practice of wife beating is not just hidden and invisible, but hard to tackle because many traditional and transitional cultures have a blind-spot about it. Dwyer et al. (1996) views the invisibility of spousal violence, especially as it affects women as stemming not necessarily from the fact that victims cover up the problem, but from the fact that society regards the problem as normal and therefore not a problem. Besides, as observed in the preceding sections, all patriarchal societies support husbands to control their wives so much that adopting abusive methods to exercise this 'control' is seen as part of the control measures and therefore normal.

Okolo (2004) further observes many women are faced with spousal violence are reluctant to let even the closest person know, and even when their experiences are those of severe pains and noticeable injuries, they simply wear guise that all is well, and go further to give false reasons to the sustained injuries all over them in a bid to conceal their bitter and heart-rending experiences.

Research on spousal violence reveals that due to the private and hidden nature of the problem, especially as it affects women, it is somewhat difficult for the law enforcement agencies and similar bodies to have reliable documented and quantifiable information on it (Dwyer et al., 1996; Okolo, 2004). This, in turn, makes it difficult for the intensity of the problem to be known in order to ascertain how much effort to put towards addressing the problem. Be that as it may, a couple of reasons have been adduced for this anomaly and they include: (a) Women fear that society would blame them for such happenings; (b) Homes where marital violence is frequent are often stigmatized as unsuccessful homes, and because no woman would want her marriage to be stigmatized, in the event of marital violence, most women would rather keep the matter concealed than 
disclose it and have their marriages stigmatized; (c) Women would never want the public to know that their husbands have abusive tendencies.

For such men, it is 'criminal' for their wives to disclose to an 'outsider' that they are women batterer, and any attempt to go against this would mean more threats and abuse. Therefore, for most women who suffer violence in the hands of their partners and refused to disclose the matter to a third party does so to avoid another hell from their husbands. It has also been suggested that another reason for women's often silence in the face of marital violence is that the public, including law enforcement agents, hardly support them to take serious actions when they manage to disclose their experience with a view to getting help. The public, including law enforcement agents usually sees marital violence as a 'family' or 'domestic' problem and so they hardly see any reason to take steps to be involved in it. Sequel to this, they suggest that the matter be resolved amicably between the couples. Okolo (2004) notes that surveys on marital violence reveal that even when the women take bold steps to get legal redress, the law enforcement agents hardly take serious legal actions. In view of this, Ferarro (1993), thus states that the traditional response of police to battering is to tell women "there is nothing we can do; this is a civil matter".

This attitude, according Frisch and Caruso (1976), is because the police are trained to diffuse marital violence by applying arbitration, mediation and negotiation deal. Similarly, Brown et al. (1997) argue that "cops and judges tend to believe that it is better for a woman to 'work out' than to give it up." If this is not the case, the men would have been severely punished when they are found guilty by a law court, but they are only asked to pay simple fines, and most of them end paying and the matter ends (Okolo, 2004).

Disturbing as the problem of violence against women is, it has been observed not just based on research on the problem, but also from direct and every day observation in the society that, in the event of violence in their homes, women still find reasons to stay in such homes. That is to say, that problem with marital violence as if affects women is not necessarily because it is common and hidden, but because society hardly sees anything wrong with it. The peculiar problem with marital violence is that women continue to live with partners who abuse them, the level of such abuse notwithstanding. The questions that arise here from are: (a) why do women stay in homes where they face different forms of torture? (b) Why do they continue to live with partners who abuse them physically and otherwise? Among other reasons, Brown et al. (1997) submit that women stay because it takes money to be able to leave. In other words, Brown et al. (1997) and Roberts (1996), are of the position that economic/financial incapacitation constitutes the first reason why women continue to stay in abusive homes. Again, it is generally agreed that most women depend on their husbands for their economic and financial upkeep while others own their economic resources jointly with their partners. For such women, it is usually not easy to abandon their little effort (investment) because of the marital violence they face; they would want to stay on because leaving would amount to losing out completely, and thus not be able to find another means of sustaining themselves. Therefore, women continue to stay with abusive partners or in abusive homes in order to meet their economic needs. Furthermore, Brown et al. (1997) argue that, "women will endure physical abuse because they do not have enough money to leave, especially if they have children".

Burns et al. (1997) also note that most women stay on in abusive homes because they have no other place to go to. According to these researchers, a number of women see their marital homes as the only home they have and, do not know where else to go to if they leave. As such, to avoid the difficulty of having no home of their own or for fear of becoming homeless, most women simply accept the only option open is to stay, the level of violence notwithstanding. In the same vein, Robert (1996) argues that most battered women who remain in violent relationship do so for fear that the abuser (partner) will hunt them and kill or maim them. There are several cases of women who become victims 
of acid bath and such other harms simply because they left their abusive partners. Thus, Brown et al. (1997) submit that statistics shows that a battered woman is more likely to be killed when she tries to leave than at any other time. Women therefore continue to live with abusive partners for fear of being killed or facing worse problems from their partners.

Intermittent reinforcement and traumatic bonding constitute another reason why battered women remain in violent relationships (Roberts, 1996). This, according to Roberts means the development of strong emotional attachments between intimate partners when the abusive partner is intermittently kind, loving and apologetic for past violent episodes and promises that the abuse will never happen again, but no sooner than the promises were made than they are broken; this time around interspersed with beating and degrading insults. In addition to the aforesaid, concern for children also makes married women in abused homes to continue to stay. Brown et al. (1997), say a woman may endure abuse for the sake of the children. Furthermore, Burns et al. (1997) and Roberts (1996) also opine that many women believe that abandoning their homes for new ones because of marital violence will ultimately affect their children negatively. Consequent upon this, it is argued that most women simply stay put irrespective of the level of violence they face in order to avoid leaving their children to suffer. Besides, Brown et al. (1997) also note that staying in abusive homes involves deep sense of sacrifice taught in many religions, especially Christianity. Also, another important explanation for women's decision to go on staying with partners who abuse them is their inability to face the shame and stigma that may follow. In the Nigerian society today, like in most other societies that are patriarchal, women are blamed and also condemned for all the wrongs that go on in their families. In fact, to the public which is more or less chauvinistic, women's inability to remain and manage their homes becomes 'the talking talk' in different drinking spots, and the fear of becoming 'the talking talk' often make them remain with their partners in spite of the violent abuse. In addition to this, there is also the issue of social conditioning targeted at women, and which, unfortunately they have swallowed hook, line, and sinker. The social conditioning inculcated into them from childhood holds that women, irrespective of their other interests, will never be fulfilled unless they are married and have children. With this social conditioning, women are therefore held responsible for keeping the families together, and the husbands, the breadwinners. According to Brown et al. (1997), when women accept this social conditioning, leaving an abusive husband means failing not only as a mother or wife, but as a woman and also as a human being. This, from all sound arguments, rests on a disastrously premise that keeps women in violent homes. From this, we could hold that women stay in abusive homes in order not to be branded as 'failures' or still not to be stigmatized and shamed as unsuccessful wives. Above all, the hope that change will someday occur also makes women stay on with abusive partners (Burns et al., 1997). Brown et al. (1997) furthermore observe that women are told that love conquers all and as such, in the face of violence, they are urged to remain in the hope that the man would change positively for the wonderful times to occur again.

\section{The concept of labour productivity}

As a concept, productivity is a concept in which both effectiveness and efficiency issues are considered (Kurosawa, 1991). Productivity and performance measurement has been considered as an essential issue for continuous improvement. Lindsay (2004) defines productivity as a measure of the ability to create goods and services from a given amount of labour capital, material, land, knowledge, time or any combination of these. Writing earlier on productivity, Gunasekaran et al. (1994) says it is applied as a measurement instrument for assessing different decisions and preventing resources' wastes. Wikimedia (2006) sees productivity as the amount of output created (in terms of goods produced or 
service rendered) per unity input used. It further views it as the average product of labour i.e. average output per worker or per worker-hour, an output which could be measured in physical terms. In other words, labour productivity is related to the concept of efficiency, which is the amount of output product produced relative to the amount of resources (time and money) that go into the production. In a similar strand, the International Labour Organization (ILO, 2006) sees labour productivity as output per unit of labour input. Fundamentally, labour productivity is a key measure of economic performance and also that, which determines the rise per capital income (ILO, 2006). In a similar vein, Wikimedia (2006) also asserts that labour productivity improves the ability to compete and make profit as well as influences the society more broadly by improving living standards, creating income and generating economic growth.

In essence, productivity helps managers to determine the subsequent investments on a new technology and to divide resources allocation (Chiou et al., 1999). Greasley (2009) stated that "productivity is used at both organizational and national level as a comparative measure of performance". In general, productivity can be defined as a ratio of outputs into inputs in a manufacturing or service process. Inputs are the production factors which are used in manufacturing process or delivering services, and outputs are the finished goods or services.

Conclusively, productivity can be defined in different ways. For Hannula (2002), ratio of outputs to inputs, the amount of using manufacturing sources appropriately, and organizational efficiency in converting inputs to outputs are cornerstones of productivity. Nevertheless, the most familiar definition for productivity is the ratio of outputs to inputs. In other words, productivity is usually measured for the following purposes:

- Assessing the technological changes.

- Verifying efficiency.

- Verifying saved costs.

- Benchmarking of manufacturing or services processes.

- Examining the living standards in the society.

From this exposition, it is clear that labour productivity is important and therefore every organization that is worth its salt must at all times focus at increasing the productivity of its workers. It is in view of this that scholars, notably, Lindsay (2004) affirm an increase in the skills of the workforce as the surest way to an increase in productivity. Put differently, productivity can be increased by stepping up the workers skills. This is because better skills make workers more efficient. Research, according to Lindsay (2006), has shown human capital to be one of the main drives of explaining the differences in the productivity. Corroborating, O'Mohoney and De Boer (2002) hold that nearly fifth of the productivity gap between Germany and the United Kingdom is due to differences in skills. In related development, Lindsay (2004) submits that labour productivity can also be increased by improving the efficiency with which the different inputs to production are used. For example, through better organization of labour or better technology investment, a positive impact on productivity can also be obtained.

Basically speaking, labour productivity is difficult to measure. Wikimedia (2006) concurs and further numerates some aspects of labour productivity that may be difficult to measure exactly or in an unbiased way to include:

- The intensity of labour effort and the quality of labour effort generally.

- The creative activity involved in producing technical innovations.

- The relative efficiency gain resulting from different systems of management, organization, coordination or engineering.

- The productive effects of some forms of labour on other forms of labour.

Braz. J. Biol. Sci., 2020, Vol. 7, No. 15, p. 79-100. 
One important reason for this, Wikimedia (2006) notes, is that these aspects of labour productivity refer mainly to its qualitative dimensions. That is to say, it is possible to observe definite increases in output without knowing what those increases should be attributed to. Wikimedia therefore argues that it is even more crucial when a large part of what is produced consists of services. Thus it concludes that a lot of what is said about productivity is based on opinion rather than empirical evidence.

In agreement with Wikimedia, International Labour Organization (ILO, 2006) contends that the best measure of productivity is the total number of hours actually worked by all persons employed. Similarly, Lindsay (2004) opines that productivity can be measured in terms of per hour work, but notes that it is disadvantageous to the extent that it would accurately indicate when productivity was unchanged. It must also be noted that the difficulty of measuring productivity constitutes a major challenge of this study. Thus, apart from looking at the issue from the position of time put into work in terms of number of hours as some scholars have submitted and as well as the number of days, this study measures productivity indirectly by examining the issues concerning workers' emotions, health and attitude to work. This is because any infringement on these areas would definitely affect an average worker's labour productivity in terms of time put into work.

\section{General consequences of violence against women on labour productivity}

Violence against women is so much of a social problem that its consequences are not just limited to women alone, but also on the entire society. It is in agreement with this position that Burns et al. (1997) submit that violence not only hurts women, but affects their productivity. Sustaining this position, it is agreed that women who are exposed to violence are associated with physical injuries such as wounds and bruises, broken bones, black eyes and swollen faces. Okolo (2004) argues that these physical injuries could lead to other health problems and which also could take longer time to heal.

Furthermore, violence also exposes women to mental health problems arising from the emotional traumas such as anxieties, depressions, insecurities and others they had been subjected to. Supporting this position, Davis (1994) says there is a higher level of anxiety, depression and somatic complaints amongst women who have suffered marital abuse, and these abuses are known to lead to lower productivity. Burns et al. (1997) opine that as a way of coping with these mental health problems, these battered women resort to drugs and alcohol in order to overcome their emotional states. Unfortunately, researchers have shown that, drugs and alcohol do not solve abusive problems rather they complicate the problems. These substances, fundamentally, worsen productivity.

Apart from the above, the loss of self confidence, the feeling of helplessness may also envelope such battered women with productivity getting worse off. From numerous studies, the psychological trauma associated with spousal violence results in a woman's low self-image, which, in turn, have negative implications for her capacity to work. Again, it is not surprising that children also suffer when their mothers are abused. According to Bradley (1994), children might suffer as a result neglect because their mother is upset and unable to take adequate care of them. The unborn baby may die or develop some abnormal traits as a result of marital violence against the mother. He also maintains that women exposure to marital violence can cause the children 'to feel upset, worried, fear, and develop such other behavioural problems such as withdrawal, aggressiveness, leave home early and become rascals, gangsters, pregnant, and perform poorly both in schools and other vocational training rather than love their father. In a similar strand, Cox (1994) upholds that children who witness violence, especially boys are more likely to grow up to become violent parents and spouses than children from non-violent homes.

The consequences of spousal violence on the society help to create a high level of violence as children learn by observing how to use violence to get what they want. Besides, it also leads to family break-up thereby creating instability in the society. Bradley 
(1994) states further that marital violence causes social problems, contributes to law and order problems and also leads to high economic cost when victims are not well enough to work. He notes further that marital violence affects society in the area of the costs in services to victims (medical treatment), assistance from the police, the courts, welfare services and so on. Thus, Bradley (1994) concludes that marital violence deprives the society of women's full potential and also make them second-class citizens under men's control.

The literature so far reviewed leaves no one in doubt that spousal violence is an umbrella that shelters numerous problems that have both men and women as its victims though; women have been the greatest casualty. Furthermore, the literature reviewed has also shown that marital violence exists in different forms and holds diverse consequences not only for women who constitutes the main victims, but also for children and the entire society.

\section{Theoretical framework}

In this work, therefore, two theories have been employed to critically analyze the work because they suit the thinking of contemporary times. The theory employed is the Gender oppression theory

\section{Gender oppression theory}

Theorists of gender oppression argue that, the plight of women is as a result of the practice of patriarchy, a kind of relationship in which men are always having a domineering interest in whatever relationship that binds them with women. In agreement with this position, Ritzer (1996) submits that 'women's situation is centrally that of being used, controlled, subjugated, and oppressed by men'. Consequent upon this, gender oppression theory is seen, fundamentally, as being perpetrated by patriarchal social structures which expect women only to be seen, admired for their beauty, and also nurtured for the convenience of men. In its entirety, gender oppression theory states that women are oppressed, actively restrained, moulded, used, and abused by men.

From this perspective, Burns et al. (1997) note that everyday women are slapped, killed, beaten, humiliated, threatened and sexually abused by their partners. Agreeing with this position, Ganny (1996) argues that physical violence is the in-thing in one out of every three (3) marriages and at some point, women are usually the victims. This is simply as a result of women being subordinates to their husbands. Under the monogamous marriage, men exercise control over their women in order to have children of undisputed paternity. Thus, in a bid to exercise this control, sometimes a number of men adopt measures that are violence prone. Since the women have to stay under men, they therefore have little or no opportunities to engage in activities that will give them strong economic standing. Consequent upon this, women continue to depend on men economically and otherwise. For this, the oppression of women is consequent upon their economic dependence on their husbands, who largely dominate the economic infrastructure, female oppression will cease if women take up paid employment. By so doing, they will earn income and then depend less or cease completely to depend on men.

Gender oppression theory has many variants such as radical feminism. This variant was propounded by Lengermam and Niebrugge (????) as quoted by Ritzer (1996). These theorists argue that, social substructures and institutions are characterized by oppression and domination, the height of them all being gender, the system of patriarchy. Thus, through patriarchal structures, men learn how to hold women in contempt, and as subhuman to be controlled. For them, patriarchy induces much violence against women, obstructing the life chances of women. Basically, radical feminists are of the position that the society is structured in a way that upholds marital violence. In other words, radical feminists believe that patriarchy is responsible for marital violence as well as other forms 
of oppression women face. They are of the view that women are everywhere oppressed by the system of patriarchy because it is the most significant structure of social inequality (Ritzer, 1996). The kernel of radical feminism is basically that, men perpetuate patriarchy with their power resource to establish control, and ensure that, the possession and control of other power resources like economic, legal and emotional, and by extension, the control of women remain within their ambit. On the whole, radicalism feminism gives an image of mutilated and bleeding woman as the visual representation of what patriarchy does.

\section{Methods}

This work adopted the ex-post facto (after-the-fact). Its justification for the work lies in the fact that the researchers cannot manipulate the independent variables because they cannot be. Kerlinger (1983) defines ex-post facto research as 'a systematic empirical inquiry in which the scientist does not have any control of independent variables because their manifestations have already occurred and cannot be manipulated. The multi-stage sampling technique which involved to a large extent a combination of two or more sampling methods at the same time was employed. This made it more precise and thorough, compared to the other sampling techniques. The multi-stage sampling technique became the most appropriate sampling technique because the population of the area of study is large. Thus, the multi-stage gave the researchers room to select samples in stages using different sampling techniques until the required population sample of 599 was reached. The target population involved in this study consisted of women in formal labour productivity in two most populated Area Councils in Abuja. The population area was given equal and independent opportunity to be selected or not selected in the study. The questionnaire was the major instrument used for data collection, and mostly close ended with few open ended questions.

\section{Results}

\section{Hypothesis one}

$\mathrm{H}_{\mathrm{o}}$ : Exposure to violence does not significantly influence the health status of women in productivity productivity

$\mathrm{H}_{1}$ : Exposure to violence does significantly influence the health status of women in

In order to test the hypothesis, the Chi-square $\left(\mathrm{x}^{2}\right)$ statistical analysis is used to test the hypothesis and the result is as presented in Table 1 .

Table 1. Chi-square $\left(\mathrm{x}^{2}\right)$ statistical analysis on the exposure to violence and the health status of women in productivity $(\mathrm{N}=595)$.

\begin{tabular}{|l|c|c|c|c|c|}
\hline \multirow{2}{*}{ Exposure to violence } & \multicolumn{5}{|c|}{ Health status of women in productivity } \\
\cline { 2 - 5 } & Below & $\mathbf{4 5 - 5 0}$ & Above 50 & Total & \multirow{2}{*}{$\mathbf{X}^{\mathbf{2}}$ Value } \\
\hline High & $80(105.88)$ & $112(127.65)$ & $158(117.06)$ & 350 & \\
\hline Low & $100(74.12)$ & $105(89.35)$ & $41(81.94)$ & 245 & \multirow{2}{*}{55.15} \\
\hline Total & 180 & 217 & 199 & 595 & \\
\hline
\end{tabular}

*Not significant at 0.05 level, critical $X^{2}=5.99, D F=2$. Source: Computed from field survey, 2019. 
The result in the Table 1 shows that the calculated $\mathrm{X}^{2}$ value of 55.15 is higher than the critical or table value of 5.99 at .05 level of significance with 2 degree of freedom. With this result the null hypothesis was rejected and the alternate hypothesis accepted. This implies that exposure to violence significantly affect the health status of women in productivity.

\section{Hypothesis two}

$\mathrm{H}_{0}$ : There is no significant relationship between exposure to violence and emotional problems among women in productivity.

$\mathrm{H}_{1}$ : There is a significant relationship between exposure to violence and emotional problems among women in productivity.

In order to test the hypothesis, the Chi-square $\left(\mathrm{x}^{2}\right)$ statistical analysis is used to test the hypothesis and the result is as presented in Table 2 .

Table 2. Chi-square $\left(\mathrm{X}^{2}\right)$ statistical analysis on the exposure to marital violence and emotional problems among women in productivity $(\mathrm{N}=595)$.

\begin{tabular}{|c|c|c|c|c|c|}
\hline \multirow{2}{*}{ Exposure to violence } & \multicolumn{5}{|c|}{ Health status of women in productivity } \\
\hline & Below & $45-50$ & Above 50 & Total & $\mathrm{X}^{2}$ Value \\
\hline High & $11(96.47)$ & $96(162.29)$ & $163(88.24)$ & 350 & \\
\hline Low & $69(67.53)$ & $\begin{array}{c}118 \\
(115.71)\end{array}$ & $58(81.94)$ & 245 & 0.52 \\
\hline Total & 164 & 281 & 150 & 594 & \\
\hline
\end{tabular}

* Not significant at 0.05 level, critical $X^{2}=5.99, D F=2$. Source: Computed from field survey, 2019.

The result indicates that the calculated $X^{2}$ value of 0.52 is less than the critical $X^{2}$ value of 5.99 at 0.05 level of significance with 2 degree of freedom. With this result, the null hypothesis was rejected. This implies that exposure to marital violence does influence emotional problems among women in productivity.

\section{Hypothesis three}

$\mathrm{H}_{0}$ : There is no significant relationship between exposure to violence and attitude of women towards productivity output.

$\mathrm{H}_{1}$ : There is a significant relationship between exposure to violence and attitude of women towards productivity output.

In order to test the hypothesis, the Chi-square $\left(\mathrm{x}^{2}\right)$ statistical analysis is used to test the hypothesis and the result is as presented in Table 3.

Table 3. Chi-square $\left(X^{2}\right)$ statistical analysis on exposure to violence and overall productivity of women (N=595).

\begin{tabular}{|l|c|c|c|c|}
\hline \multirow{2}{*}{ Exposure to violence } & \multicolumn{3}{|c|}{ Attitude to productivity of women } \\
\cline { 2 - 4 } & Positive & Negative & Total & $\begin{array}{c}\boldsymbol{X}^{\mathbf{2}} \\
\text { Value }\end{array}$ \\
\hline High & $215(217.65)$ & $135(135.35)$ & 350 & \multirow{2}{*}{0.21} \\
\hline Low & $155(152.35)$ & $90(92.65)$ & 245 & \\
\hline Total & 370 & 225 & 595 & \\
\hline
\end{tabular}

* Not significant at 0.05 level, critical $\mathrm{X}^{2}=3.84, \mathrm{df}=1$. Source: Computed from field survey, 2019. 
The result indicates that the calculated $\mathrm{X}^{2}$ value of 0.21 is less than the critical $\mathrm{X}^{2}$ value of 5.99 at 0.05 level of significance with 2 degree of freedom. With this result, the null hypothesis was rejected. This implies that exposure to marital violence does influence emotional problems among women in productivity.

\section{Discussion}

The discussion of the findings falls completely in line with the report of Barnett and Lavioette (1993) that women in the United States make about 1,453,437 medical visits every year to treat injuries resulting from assaults by spouse. The findings also agree with that of Robert (1996) who reports that United States survey data estimate holds the number of visits by women for medical care resulting from domestic violence to be 28,700 visits to a hospital emergency room, 39,000 visits to physicians' office, 21,000 inpatient hospitalization and 99,800 days of hospitalization. These visits to the hospital by women who are subjected to violence by their spouses are usually there to treat physical injuries like bruises, broken bones, black eyes, swollen faces and psychological and physiological health problems resulting from their subjection to martial violence. In essence, exposure to marital violence does significantly influence the health status of women in the formal labour sector. The health status of the subject plays a significant role to determine labour productivity. For women in labour productivity, both private and public, it is obvious that if their health is affected, their labour productivity will also be affected. There is a popular saying that "health is wealth". It is only when a person is healthy that he or she can be strong enough to be productive.

On exposure to marital violence and emotional problems among women in the labour productivity sector, the report of Davis (1994) confirms that women who suffer marital violence have significantly higher level of anxiety, depression and somatic complaints than women who have not suffered such abuse. It can be deduced that because of these emotional problems, the productivity of subjects in their work place will certainly experience a short fall. Individuals can only function effectively when they are emotionally stable. Put differently, marital violence affects the emotional state of women, and this turn affects productivity negatively in two opposite directions - when one is increasing the other is decreasing and vice versa. This means that when exposure to marital violence increases, their emotional health deteriorates and when their exposure is reduced their emotional health improves. The result of the analysis of hypothesis three corroborates the assertions that when an individual says, "I don't like my job", he or she is expressing his or her attitude towards his or her job, and this attitude in turn reflects in how he or she performs the job assigned to him or her. It is attitude towards work that determines how productive a worker can be, or what is described in this study as labour productivity.

\section{Conclusion and recommendations}

Women constitute the main subjects of this study even though men were included. They represent an important population group in Nigeria and by functioning as part of the overall labour force; they make meaningful contributions to development and general societal well-being. Violence reduces the labour-productivity of employed women. The frequency of the cruelty against women has not only become alarming, but a cornerstone for concern in the society because most victims suffer in vain. Most often, they are killed, seriously injured or permanently disabled. Based on this, women as well as men should consult with professional marriage counselors or social workers before and after marriage. Premarital counselling from social workers would afford them the opportunity to know ahead of time the challenges of marriage and the need to prepare for such, so as to avoid marital violence. For already married women as well as men, they must regularly 
see a social worker for marriage and family therapy. These two forms of counselling would help them adjust properly to marital and family life without running into unnecessary crises. The latter forms of counsel are also important to the extent that even if the crises would have to end up in divorce or separation, the two forms of analyses would help them do so without introducing more violence. Finally, this study concludes that women facing marital violence must understand that concealing it from the public under the guise that all is well as the study has shown while in reality all is not well is not the way out of the problem. Rather, they should freely talk about their experiences with other women, especially those who are faced with the same problem. By so doing, they could form an alliance and seek for help from appropriate social agencies.

In view of this, the study recommends as follows:

1. Exposure to violence against women significantly affects employed women in the area of their health, emotions and attitude towards work. Incidentally, these factors function directly or indirectly to determine how well an individual would do in both work place and other endeavours and therefore all hands must be deck to stop it.

2. Women as well as men should consult with professional marriage counselors or social workers before and after marriage. Before marriage, premarital counseling from social workers would afford them the opportunity to know ahead of time the challenges of marriage and the need to prepare for such, so as to avoid marital violence. For already married women as well as men, they must regularly see a social worker for marriage and family counselling. These two forms of counselling would help them adjust properly to marital and family life without running into unnecessary crises. The latter forms of counselling are also important to the extent that even if the crises would have to end up in divorce or separation, the two forms of counselling would help them do so without introducing more violence.

3. The society at large also has a great responsibility towards tackling the problem of violence against women. Law enforcement agents and indeed the general public should be willing to listen to women who complain of being subjected to marital violence. Apart from listening to them they should go further to help them out by taking practical steps to look into such complaints and assist where and when necessary. They should not see the problem as a mere domestic affair and assume that the couples involved would resolve the issue amicably.

4. Furthermore, non-governmental organizations, women organizations and the media, all have crucial roles to play. These bodies could function to create awareness on the dangers of marital violence, as well as mobilize society members towards addressing the conditions that give rise to the problem. In addition, educational and religious institutions should make efforts to educate the youths and indeed the entire public on the ills associated with marital violence particularly wife abuse, with a view to getting them unlearn such violent behaviours and rather learn to be more accommodating in their relationship with their partners.

5. Above all the government should make and ensure the strict enforcement of laws that would protect women's rights, as well as deter their partners from subjecting them to marital violence. On the part of law enforcement agents, they should see to it that reported cases of marital violence against women are thoroughly investigated. They should also stamp down their feet to mete out appropriate punishment on defaulting men. This would certainly go a long way to discourage men generally from assaulting their partners, their level of provocation notwithstanding.

\section{Confict of interesses}

Authors declare that they have no conflict of interests.

Braz. J. Biol. Sci., 2020, Vol. 7, No. 15, p. 79-100. 


\section{References}

Abayomi, A. A.; Kolawole, T. O. Domestic violence and death: Women as endangered gender in Nigeria. American Journal of Sociological Research, v. 3, no. 3, p. 53-60, 2013. https://doi.org/10.5923/j.sociology.20130303.01

Amnesty International. Unheard voices. Nigeria: Amnesty International, 2005. Available from: <http://web.amnesty.org/library/index/engafr440042005>. Accessed on: Jul. 23, 2019.

Barnett, O. W.; Laviolette, A. D. It could happen to anyone: Why battered women stay. London: Sage Publication, 1993.

Bart, P. B.; Moran, E. G. (Eds.). Violence against woman: The bloody footprints. London: Sage Publication, 1993.

Bradley, C. Why male violence against women is a development issue: Reflections from Paupau, New Guinea. In: Davies, M. (Ed.). Women and violence: Realities and responses worldwide. New York: Zed Books, 1994.

Brown, L.; Dubau, F.; McKeon, M. Y. D. Stop domestic violence: An action plan for saving lives. New York: St. Martin's Griffin, 1997.

Burns, A. A.; Lovich, R.; Maxwell, Y.; Shapiro, K. Where women have no doctor: A health guide for women. California: Macmillan, 1997.

Carrilo, R. Battered dream: Violence against women as an obstacle to development. New York: United Nation Development Funds, 1992.

Chiou, W. C.; Kuo, H. W.; Lu, I. Y. A technology oriented productivity measurement model. International Journal of Production Economics, v. 60, no. 1, p.69-77, 1999. https://doi.org/10.1016/S0925-5273(98)00187-X

Chukwu, C. C.; Okey, A. The perils of sexual violence against women: A case of Abakaliki and Ikwo Local Government Areas of Ebonyi State, South-East Nigeria. International Journal of Applied Research and Studies, v. 4, no. 5, 2015.

Collins, K. S.; Schoen, C.; Joseph, S.; Duchon, L.; Simantov, E.; Yellowitz, M. Health concerns across a woman's lifespan: The Commonwealth Fund 1998 Survey of Women's Health. 1999. Available from: <https://www.commonwealthfund.org/publications/fundreports/1999/may/health-concerns-across-womans-lifespan-commonwealth-fund-

1998>. Accessed on: Jul. 23, 2019.

Cox, E. S. Gender violence and women's health in Central American. In: Davis, M. (Ed.). Women and violence: Realities in responses worldwide. New York: Zed Books, 1994. p. 118-133.

Davis, M. (Ed.). Women and violence: Realities and responses worldwide. New York: Zed Books, 1994.

Dwyer, D. C.; Smokowsk, P. R.; Bricout, Y. C.; Wodarski, Y. S. Domestic violence and women battering: Theories and practice implications. In: Roberts, A. R. (Ed.). Helping battered women: New perspectives and remedies. New York: Oxford University Press, 1996. p. 6782.

Eze-Anaba, I. Domestic violence and legal reforms in Nigeria: Prospects and challenges. Cardozo Journal of Law \& Gender, v. 14, no. 1, p. 21-60, 2007.

Ferarro, K. J. Cops, courts and women battering. In: Bail, P. B.; Moran, E. G. (Eds.). Violence against women: The bloody footprints. London: Sage Publication, 1993. p. 165-176. 
Ganny, M. Domestic violence: The case of wife abuse and its effects on women's contribution to national development. In: Oruwari, Y. (Ed.). Women, development and the Nigerian environment. Ibadan: Vantage Publishers, 1996.

Greasley, A. Operation management. 2. ed. Chichester: Wiley \& Sons, 2009.

Gunasekaran, A.; Korukonda, A. R.; Virtanen, I.; Yli-Olli, P. Improving productivity and quality in manufacturing organizations. International Journal of Production Economics, v. 36, no. 2, p. 169-183, 1994.

Haaga, P. T.; Aja, E. F.; Chukwuemeka, O. A. Violence against women and its implications for peace and security in Nigeria. International Journal of Peace and Conflict Studies, v. 2, no. 3, p. 27-40, 2015. Available from: <http://rcmss.com/2015/ ijpcs/september/VIOLENCE AGAINST WOMEN AND ITS IMPLICATIONS FOR PEACE AND SECURITY IN NIGERIA.pdf>. Accessed on: Jul. 23, 2019.

Hannula, M. Total productivity measurement based on partial productivity ratios. International Journal of Production Economics, v. 78, no. 1, p. 57-67, 2002. https://doi.org/10.1016/S0925-5273(00)00186-9

Holy Bible. The New King James Version. Nashville: Thomas Nelson Publishers, 1982.

ICPD - International Conference on Population and Development. 1994. Available from: $<$ https://www.unfpa.org/icpd>. Accessed on: Jul. 23, 2019.

Ilika, A. L. Women's perception of partner violence in a Rural Igbo Community. African Journal of Reproductive Health, v. 9, no. 3, p. 77-88, 2005.

ILO - International Labour Organization. Key indicators of the Iabour market. Geneva: International Labour Office, 2006.

Kerlinger, F. N. Foundations of behavioural sciences. New York: Holt, Rinehart and Wilson, 1983.

Kurosawa, K. Productivity measurement and management at the company level: The Japanese experience. Amsterdam: Elsevier, 1991.

Lindsay, C. Labour market trends. London: Office for National Statistics, 2004.

Marelli, E.; Signorelli, M. Employment, productivity and models of growth in the EU. International Journal of Manpower, v. 31, no. 7, p. 731-754, 2010.

Margolin, G.; Burman, B. Wife abuse versus marital violence: Different terminologies, explanations, and solutions. Clinical Psychology Review, v. 13, no. 1, p. 59-73, 1993. https://doi.org/10.1016/0272-7358(93)90008-A

Nigeria Report. 2012. Available from: <https://www.britishcouncil.org/sites/ default/files/british-council-gender-nigeria2012.pdf>. Accessed on: Jul. 23, 2019.

O'Mahoney, M.; De Boer, W. Britain productivity performance. London: NIERS, 2002.

OAU - Organization for African Unity. African Charter on Human and Peoples' Rights. Nairobi, Kenya: OAU, 1986. Available from: <https://www.ihrda.org/2012/10/africancharter-on-human-and-peoples-rights-2/>. Accessed on: Jul. 23, 2019.

Okolo, G. U. Violence against women. Baye Communications, 2004.

Oxford Learner's Dictionary. 1995.

Braz. J. Biol. Sci., 2020, Vol. 7, No. 15, p. 79-100. 
PRB - Population Reference Bureau. Domestic violence: An ongoing threat to women in

Latin America and the Caribbean. PRB, 2001. Available from: <https://www.prb.org/domesticviolenceanongoingthreattowomeninlatinamericaand thec aribbean/>. Accessed on: Jul. 23, 2019.

Ritzer, G. Sociological theory. Singapore: McGraw Hill Book, 1996.

Roberts, A. R. Myths and realities regarding battered women. In: Roberts, A. R. (Ed.). Helping battered women new perspectives and remedies. New York: Oxford University Press, 1996.

Uchem, R. N. Overcoming women's subordination: An Igbo African and Christian perspective. Enugu: Snapp Press, 2001.

Uchendu, E. Masculinity and Nigerian youths. Nordic Journal of African Studies, v. 16, no. 2, p. 279-297, 2005. Available from: <https://www.njas.fi/njas/article/view/71/64>. Accessed on: Jul. 23, 2019.

Ugube, R. B. Women and gender studies. Abuja: Sir Kuf Ventures, 2004.

UN - United Nation. Beijing Declaration. New York: United Nations, 1995. Available from: $<$ https://www.un.org/womenwatch/daw/beijing/platform/declar.htm>. Accessed on: Jul. 23, 2019.

UN - United Nation. Convention on the Elimination of All Forms of Discrimination against Women. New York: United Nations, 1979. Available from: $<$ https://www.ohchr.org/en/professionalinterest/pages/cedaw.aspx>. Accessed on: Jul. 23, 2019.

UN - United Nation. Declaration on the Elimination of Violence Against Women. New York: United Nations, 1993. (United Nation General Assembly Resolution Document, RES/48/104; 1993). Available from: <https://www.ohchr.org/en/professionalinterest/ pages/violenceagainstwomen.aspx>. Accessed on: Jul. 23, 2019.

UN - United Nation. No development tool more effective than education of girls, empowerment of women says secretary-general in address to women's health coalition. 2004. Available from: <https://www.un.org/press/en/2004/sgsm9118.doc.htm>. Accessed on: Jul. 23, 2019.

Vatican. Code of Canon Law. Vatican: 1917. Available from: <http://www.vatican.va/ archive/cod-iuris-canonici/cic_index_en.html>. Accessed on: Jul. 23, 2019.

Wikimedia. Productivity. 2006. Available from: <http://en.wikipedia.org/wiki/ productivity>. Accessed on: Jul. 23, 2019.

License information: This is an open-access article distributed under the terms of the Creative Commons Attribution License, which permits unrestricted use, distribution, and reproduction in any medium, provided the original work is properly cited. 